UDK 347.447.54:347.426.6(4-672EU)

https://doi.org/10.18485/union_pf_ccr.2021.ch1

Prof. dr sc. Maja Bukovac Puvača*

\title{
ODGOVORNOST NA TEMELJU KRIVNJE I OBJEKTIVNA ODGOVORNOST ZA ŠTETU U ODŠTETNOM PRAVU EU
}

\begin{abstract}
Apstrakt: Cilj ovog rada bio je istražiti postoji li na europskoj razini temelj za razlikovanje odgovornosti na temelju krivnje i objektivne odgovornosti za štetu i određivanje granica njihove primjene. Europski zakonodavac, zbog posredne nadležnosti za intervencije u privatno pravo država članica, ujednačavanju pravila o odgovornosti za štetu pristupa selektivno i parcijalno i zato u europskim propisima jasno određenje o kojoj se vrsti odgovornosti radi u pravilu izostaje. Soft law izvori europskog odštetnog prava, PETL i Knjiga VI DCFR-a, pokušali su sustavno urediti slučajeve odgovornosti na temelju krivnje i objektivne odgovornosti za štetu, ali ni oni posve uspješno, ostavivši nacionalnim sustavima mogućnost propisivanja dodatnih kategorija objektivne odgovornosti.
\end{abstract}

Ključne riječi: krivnja, objektivna odgovornost, opasna stvar/djelatnost, PETL, DCFR.

\section{UVOD}

Svako pozivanje na „europsko odštetno pravo“ (European tort law) i/ili „odštetno pravo Europske unije" (EU tort law) za sobom povlači problem jasnog definiranja što se pod tim pojmovima razumijeva i njihova odnosa prema nacionalnim odštetnim pravima država članica. ${ }^{1} \mathrm{U}$ ovom radu pod europskom razinom odštetnog prava podrazumijevamo pravila o izvanugovornoj odgovornosti za štetu koja svoj izvor imaju u europskim propisima (prvenstveno direktivama i uredbama), praksi Suda EU i soft law izvorima europskog odštetnog prava. Posljedica izvedene (posredne) nadležnosti na temelju koje Unija u privatno pravo država članica može intervenirati samo u svrhu uklanjanja prepreka funkcioniranju jedinstvenog tržišta jeste to da europski zakonodavac samo selektivno i parcijalno donosi određena pravila o odgovornosti za štetu. Primjena tih pravila pred nacionalnim sudovima država članica predstavlja izazov, a pitanje njihova

* Sveučilište u Rijeci, Pravni fakultet, Katedra za građansko pravo, e-mail: bukovac@pravri.hr

1 Detaljnije analize tih problema prelaze okvire ovoga rada. Vidi o tome: Giliker, P., 2017, What do we mean by „EU tort law“?, u: Giliker, P. (ed.), Research handbook on EU tort law, Edward Elgar Publishing, Cheltenham, Northampton, pp. 1-25 i Van Dam, C., 2013, European Tort Law, Oxford University Press, New York, pp. 4-8. 
utjecaja na nacionalne odštetnopravne sustave svakako će još dugo vremena biti predmetom rasprava. $^{2}$

Budući da je pitanje vrste odgovornosti za štetu svakako jedno od temeljnih pitanja svakog slučaja odgovornosti u nacionalnim pravnim sustavima, željeli smo provjeriti je li tome tako i na europskoj razini, odnosno je li razlikovanje odgovornosti na temelju krivnje i objektivne odgovornosti i na europskom nivou od takvog značaja. Iako je svjestan velikih razlika u odštetnopravnim sustavima država članica, europski zakonodavac u pravilu pred njih postavlja zadatak pravilne implementacije i ostvarenja cilja europskih propisa u kojima na pitanje vrste odgovornosti nije izričito odgovorio. I u slučajevima odgovornosti za štetu koji su se razvili isključivo kroz praksu Suda EU (odgovornost država članica i odgovornost same Unije zbog povreda europskog prava) teško je odrediti o kojoj se tu vrsti odgovornosti radi, jer krivnju štetnika ne ističu kao posebnu pretpostavku odgovornosti. Nešto detaljnije i svakako sustavnije određenje vrste odgovornosti za štetu na europskom nivou možemo pronaći jedino u neobvezujućim pravilima o odgovornosti za štetu, nastalim kao rezultat dugogodišnjeg rada brojnih pripadnika akademske zajednice i pravnika praktičara, vođenih idejom da, usprkos velikim razlikama u nacionalnim pravima, postoji mogućnost pronalaska zajedničkih pravila o odgovornosti za štetu, pa tako i vrsti te odgovornosti.

\section{PROPISI EUROPSKE UNIJE}

\subsection{OPĆENITO O PRAVILIMA O VRSTI ODGOVORNOSTI ZA ŠTETU U PROPISIMA EUROPSKE UNIJE}

Europski propisi vrlo rijetko spominju krivnju, nešto češće koriste odredbe o prebacivanju tereta dokaza, ali uglavnom su to pravila o odgovornosti koju je teško identificirati kao odgovornost na temelju krivnje ili onu objektivnu. ${ }^{3}$ Rizik hoće li neki slučaj odgovornosti za koji pravo na naknadu štete proizlazi iz europskog prava biti ispravno interpretiran u nacionalnim sustavima i time ostvaren cilj europskog propisa isključivo je na državama članicama, a budući da se europske odredbe moraju tumačiti u kontekstu konkretnog europskog propisa, čak ni sadržajno slične odredbe o odgovornosti iz različitih europskih propisa ne moraju imati isti karakter, odnosno biti jednako kvalificirane.

Zbog svoje pravne prirode ${ }^{4}$ direktive ne mogu biti previše precizne i zato u njihovim odredbama i ne treba očekivati detaljan i jasan koncept odgovornosti

2 O kompleksnom odnosu europskog odštetnog prava i nacionalnih odštetnih prava država članica vid. Leczykiewicz, D., Compensatory remedies in EU law: the relationship between EU law and national law, u: Giliker, P. (ed.), 2017, Research handbook on EU tort law, Cheltenham, Northampton, Edward Elgar Publishing, pp. 63-92.

3 Pregled odredaba nekih od direktiva koje direktno ili indirektno spominju krivnju i/ili teret njena dokazivanja vid. kod: Lukas, M., Fault Liability, u: Koziol, H., Schulze, R. (eds.), 2008, Tort Law of the European Community, Wien, Springer, pp. 81-102.

4 Direktive obvezuju države članice na postizanje određenih rezultata, prepuštajući im izbor forme i metoda njihova postizanja. 
na temelju krivnje i/ili objektivne odgovornosti za štetu. Uredbe, čije su odredbe izravno primjenjive, ipak ostavljaju veću mogućnost da se njihova pravila o odgovornosti u nacionalnim sustavima država članica u većem stupnju kvalificiraju i primjenjuju na jednak način. ${ }^{5}$

\subsection{PRAVILA O VRSTI ODGOVORNOSTI ZA ŠTETU U DIREKTIVI 85/374/EEZ I DIREKTIVI 2014/104/EU}

Već trideset i pet godina dio europskog pravnog poretka je Direktiva 85/374/ $E E Z,{ }^{6}$ za temu ovog rada značajna po tome što je izričito propisala objektivnu odgovornost za štete od neispravnog proizvoda. ${ }^{7}$ Međutim, već je tada postalo jasno da će se na europskom nivou jako teško donositi propisi koji će na jedinstven način urediti pojedini slučaj odgovornosti. Kao kompromisno rješenje ovom je direktivom prihvaćeno pravilo o „razvojnom riziku“ ${ }^{8}$ kao mogućem egzoneracijskom razlogu i dopušteno državama članicama da ga svojim pravom ne priznaju kao razlog oslobođenja odgovornosti proizvođača. ${ }^{9}$ Neki autori drže da

5 S obzirom na pravnu prirodu uredbi i obvezu neposredne primjene njihovih odredaba, isključena je primjena nacionalnih pravila o subjektivnoj i objektivnoj odgovornosti za štetu. Pitanje kvalifikacije vrste te odgovornosti moglo bi se pojaviti kao sporno samo ako i u mjeri u kojoj neki nacionalni poredak o elementima odgovornosti koji nisu regulirani uredbom sadrži opća pravila različita za odgovornost na temelju krivnje i onu objektivnu.

6 Direktiva Vijeća 85/374/EEZ od 25. srpnja 1985. o približavanju zakona i drugih propisa država članica u vezi s odgovornošću za neispravne proizvode, Sl. list EU L 210, 7. 8. 1985, str. 29-33 (Sl. list, posebno izdanje na hrvatskom jeziku, poglavlje 15, svezak 22, str. 3-7), izmijenjena i dopunjena Direktivom 1999/34/EZ Europskog parlamenta i Vijeća od 10. svibnja 1999. o izmjeni Direktive Vijeća 85/374/EEZ od 25. srpnja 1985. o usklađivanju zakona i drugih propisa država članica u vezi s odgovornošću za neispravne proizvode (Sl. list EU L 141, 4. 6. 1999, str. 20-21) (Sl. list, posebno izdanje na hrvatskom jeziku, poglavlje 15, svezak 12, str. 43-44) (Direktiva 85/374/EEZ).

7 Ovu se Direktivu u literaturi naziva i „djedom“ europskog odštetnog prava, jer su važni koncepti odgovornosti za štetu država članica morali biti revidirani. Njena implementacija nije prošla bez većih problema, bilo je značajnih kašnjenja, nepravilne implementacije, postupaka protiv nekih članica (Francuske, Grčke, Velike Britanije, Portugala, Danske). Ova je „borba“ u fokus stavila europsku dimenziju odštetnog prava i jasnim učinila koliziju EU prava i tradicionalne strukture i načela odštetnog prava. Knetsch, J., European tort law in Western Europe, u: Giliker, P. (ed.), 2017, Research handbook on EU tort law, Cheltenham, Northampton, Edward Elgar Publishing, pp. 346-349.

8 Jednom od dvije opcijske odredbe Smjernice 85/374/EEZ (članak 15. stavak 1. točka b), dopušteno je državama članicama isključiti razvojni rizik, odnosno svojim pravom predvidjeti odgovornost proizvođača i kada dokaže da stanje znanosti i tehničkog znanja u vrijeme stavljanja proizvoda u promet nije omogućavalo otkrivanje nedostatka. Više o razvojnom riziku i raspravama koje je izazvao vid. Baretić, M., 2005, Odgovornost za neispravan proizvod, u: Baretić, M. et al., 2005, Novi Zakon o obveznim odnosima - najznačajnije izmjene - novi instituti, Inženjerski biro, Zagreb, str. 251-254 i Petrić, S., Bukovac Puvača, M., 2008, Problem razvojnih rizika kod odgovornosti za neispravan proizvod, Zbornik radova Aktualnosti gradanskog i trgovačkog zakonodavstva i pravne prakse, 6, str. 208-223.

9 Iako je cilj bio uvođenje objektivne odgovornosti „budući da je odgovornost bez krivnje proizvođača svojstvena našem dobu[...]“, već se u samo nekoliko odlomaka dalje istaklo da „pra- 
se ta Direktiva, s gledišta zaštite potrošača, pokazala prilično razočaravajućom, posebno jer se maksimalna harmonizacija s gledišta internog tržišta može ocijeniti opravdanom, ali s gledišta potrošača država u kojima je dotadašnji stupanj zaštite bio viši sigurno ne. ${ }^{10}$

Direktiva 2014/104/EU, ${ }^{11}$ koja sadrži najdetaljnije uređenje odgovornosti za štetu od svih trenutno važećih direktiva, na kraju je ipak usvojena bez odredbe o krivnji kao pretpostavci odgovornosti za štetu. ${ }^{12}$ Države članice koje u nacionalnom pravu predviđaju krivnju kao pretpostavku odgovornosti za štetu mogu je zadržati u mjeri u kojoj je to u skladu sa sudskom praksom Suda EU, načelima učinkovitosti i jednakovrijednosti te samom tom Direktivom. ${ }^{13} \mathrm{U}$ praksi je, međutim, teško ostvariv „suživot“ objektivnog pristupa samoj povredi pravila tržišnog natjecanja i krivnje kao pretpostavke odgovornosti za tom povredom prouzročenu štetu. Budući da su postupci za naknadu štete neovisni o postupcima pred regulatornim tijelima, pravo na naknadu štete ne ovisi o prethodnom postojanju odluke Komisije ili nadležnog nacionalnog tijela o postojanju povrede. ${ }^{14}$ Ali, ako takva prethodna odluka postoji, pitanje je djeluje li samo u smjeru postojanja protupravnosti ili i same krivnje kao pretpostavke odgovornosti za štetu. Zato se postavlja pitanje može li krivnja koju je ustanovilo tijelo nadležno za utvrđivanje povrede u svrhu propisivanja novčane kazne poduzetniku biti dovoljna za utvrđenje da postoji i krivnja kao pretpostavka za odgovornost za štetu $\mathrm{u}$ nacionalnom pravu. ${ }^{15}$

vedna raspodjela rizika između oštećene osobe i proizvođača podrazumijeva da proizvođač ima mogućnost osloboditi se odgovornosti ako dokaže postojanje određenih okolnosti koje ga oslobađaju krivnje“, s tim da države članice treba da imaju mogućnost da se „takva okolnost oslobađanja krivnje ne dopusti“ (Preambula Direktive).

10 White, F., Directive 85/374/EEC concerning liability for defective products: in the name of harmonisation, the internal market and consumer protection, u: Giliker, P. (ed.), 2017, Research handbook on EU tort law, Edward Elgar Publishing, Cheltenham, Northampton, p. 129. Zanimljiv je i zaključak da su odredbe te direktive mnogo češće predmet teorijskih rasprava nego što se zapravo primjenjuju u praksi. Howells, G., Is European Product Liability Harmonised?, u: Koziol, H., Schulze, R. (eds.), 2008, Tort Law of the European Community, Wien, Springer, p. 121.

11 Direktiva 2014/104/EU Europskog parlamenta i Vijeća od 26. studenoga 2014. o određenim pravilima kojima se uređuju postupci za naknadu štete prema nacionalnom pravu za kršenje odredaba prava tržišnog natjecanja država članica i Europske unije, Sl. list Europske unije, $L$ 349, 5. 12. 2014, str. 1-19 (Direktiva 2014/104/EU).

12 Tijekom donošenja Direktive, problem krivnje kao pretpostavke odgovornosti za štetu u nacionalnim pravnim sustavima jasno je identificiran i razmatrani su različiti prijedlozi. Vid. Okeoghene, O., Sanchez-Graells, A., The interface of EU and national tort law: competition law, u: Giliker, P. (ed.), 2017, Research handbook on EU tort law, Cheltenham, Northampton, Edward Elgar Publishing, pp. 161-162.

13 Preambula Direktive, t. 11.

14 Više o ovom slučaju odgovornosti za štetu, te dvije vrste tužbi za naknadu štete vid. Bukovac Puvača, M., Butorac, V., 2008, Izvanugovorna odgovornost za štetu prouzročenu povredom pravila tržišnog natjecanja, Zbornik radova Šestog međunarodnog savjetovanja Aktualnosti građanskog i trgovačkog zakonodavstva i pravne prakse, str. 246-272.

15 Okeoghene, O., Sanchez-Graells, A., 2017, pp. 161-162. 


\subsection{VRSTA ODGOVORNOSTI ZA ŠTETU IZ UREDBE (EU) 2016/679}

Uredba (EU) 2016/679 ${ }^{16}$ u članku 82. stavak 3. propisuje: Voditelj obrade ili izvršitelj obrade izuzet je od odgovornosti na temelju stavka 2. ako dokaže da nije ni na koji način odgovoran za događaj koji je prouzročio štetu. Izričaj Uredbe nije bitno različit u odnosu na onaj iz prethodno važeće Direktive ${ }^{17}$ osim što dodatak „ni na koji način“ svakako dodatno naglašava strogost te odgovornosti.

Potencijalno odgovorna osoba mora dokazati da je obradu osobnih podataka vršila u skladu s pravilima Uredbe i drugih propisa kojima je ta obrada regulirana. U kojoj će se mjeri pristup nacionalnih sudova teretu dokazivanja da nije ni na koji način odgovoran za događaj koji je prouzročio štetu razlikovati, tek predstoji vidjeti. Iako krivnja nije Uredbom propisana kao pretpostavka odgovornosti za štetu, namjeri ili nepažnji potencijalno odgovornih osoba pozornost moraju posvetiti nadzorna tijela pri izricanju upravnih novčanih kazni (članak 83. st. 2. (b) i 3. Uredbe). ${ }^{18}$ Krivnja je, dakle, i ovdje jedan od elemenata procjene protupravnosti, a ne samostalna pretpostavka odgovornosti za štetu.

\section{PRAKSA SUDA EU}

Europski slučaj odgovornosti za štetu koji se često prikazuje kao onaj koji ima visok stupanj autonomije u odnosu na nacionalna pravila o odgovornosti je odgovornost države za štetu zbog povrede europskog prava. Od samih početaka razvoja toga instituta $\left(\right.$ Francovich $^{19}$, Brasseri $^{20}$ ), krivnja nije razmatrana kao samostalna pretpostavka odgovornosti države za štetu. Sud EU je u slučaju Brasserie kao pretpostavke odgovornosti države za štetu naveo: da je namjera pravnog pravila koje je prekršeno dodjela subjektivnog prava pojedincu, da je povreda dovoljno ozbiljna, te da postoji izravna uzročna veza između povrede obveze države i štete koju je pojedinac pretrpio. ${ }^{21}$ Nacionalni sudovi odlučujući

16 Uredba (EU) 2016/679 Europskog parlamenta i Vijeća od 27. travnja 2016. o zaštiti pojedinaca u vezi s obradom osobnih podataka i o slobodnom kretanju takvih podataka te o stavljanju izvan snage Direktive 95/46/EZ (Opća uredba o zaštiti podataka), Sl. list Europske unije, L 119, 4. 5. 2016, str. 1-88 (Uredba (EU) 2016/679).

17 Direktiva 95/46/EZ (Direktiva 95/46/EZ Europskog parlamenta i Vijeća od 24. listopada 1995. o zaštiti pojedinaca u vezi s obradom osobnih podataka i o slobodnom protoku takvih podataka (SL L 281, 23. 11. 1995) (Direktiva 95/46/EZ) u članku 23. stavak 2. je propisivala da se nadzornik može u cijelosti ili djelomično izuzeti od ove odgovornosti ako dokaže da nije odgovoran za slučaj koji je doveo do štete. Hrvatski je zakonodavac ovu odgovornost bio podvrgnuo općim pravilima odgovornosti za štetu, dakle onima o odgovornosti na temelju pretpostavljene krivnje iz članka 1045. Zakona o obveznim odnosima (Narodne novine, br. 35/05, 41/08, 125/11, 78/15 i 29/18).

18 Iako su postupci po pritužbi nadzornim tijelima i sudski postupci za naknadu štete zbog navodnih kršenja odredaba Uredbe posve neovisni, u puno boljoj se procesnoj poziciji nalazi oštećenik koji raspolaže odlukom nadzornog tijela kojom je već utvrđeno postojanje povrede.

19 Presuda od 19. studenog 1991, Andrea Francovich i Danila Bonifaci i dr./Republika Italija, Spojeni predmeti C-6 i 9/90, ECR I-05357, ECLI:EU:C:1991:428.

20 Presuda Suda od 5. ožujka 1996., Brasserie du Pêcheur SA/Bundesrepublik Deutschland i The Queen Secretary of State for Transport, ex parte: Factortame Ltd i dr., Spojeni predmeti C-46/93 i C-48/93, ECR I-1066., ECLI:EU:C:1996:79.

21 Brasserie, t. 51. 
o odgovornosti države ne smiju primijeniti pravilo nacionalnog prava koje bi postrožilo tu odgovornost, odnosno nametnulo još neke dodatne pretpostavke iste, npr. krivnju države. Međutim, za odluku o odgovornosti države krivnja nije posve irelevantna, jer ona može utjecati na kvalifikaciju povrede kao „dovoljno ozbiljne ${ }^{\text {“22 }}$ i u tom smislu se krivnja može razmatrati kao element protupravnosti. Upravo se za dovoljno ozbiljnu povredu kao pretpostavku odgovornosti države za štetu, često prožetu pojmom krivnje iz nacionalnog pravnog sustava, ističe da je to jedna od najvećih prepreka ostvarivanju zahtjeva za naknadu štete pred nacionalnim sudovima država članica. ${ }^{23}$

Za izvanugovornu odgovornost Unije u smislu članka 340. stavak 2. UFEU-a, prema praksi Suda potrebno je ispunjenje istih pretpostavki kao i za odgovornost država članica: nezakonito postupanje njezinih tijela, stvarna šteta i uzročna veza između njih. ${ }^{24}$ Navedene tri pretpostavke moraju u svakom slučaju biti kumulativno ispunjene. ${ }^{25} \mathrm{Za}$ nezakonito postupanje Unije potrebna je dovoljno ozbiljna povreda pravnog pravila kojim se pojedincima dodjeljuju prava, a ona postoji ako je institucija Unije očito i grubo prekoračila granice svoje diskrecijske ovlasti. ${ }^{26}$ I u ovom slučaju, dakle, krivnju možemo razmatrati samo kao jedan od više elemenata procjene ozbiljnosti povrede. ${ }^{27}$

\section{SOFT LAW IZVORI PRAVILA O IZVANUGOVORNOJ ODGOVORNOSTI ZA ŠTETU (PETL I DCFR)}

\subsection{OPĆENITO O PETL I DCFR}

Najznačajnije soft law izvore europskog odštetnog prava svakako predstavljaju Načela europskog odštetnog prava ${ }^{28}$ (PETL) i Knjiga VI Nacrta zajedničkog

22 Brasserie, t. 78-79.

23 Granger, M. P. F., Francovich liability before national courts: 25 years on, has anything changed? u: Giliker, P. (ed.), 2017, Research handbook on EU tort law, Cheltenham, Northampton, Edward Elgar Publishing, p. 115.

24 Vid. npr.: Presuda od 11. srpnja 1997, Oleifici Italiani/Komisija, T-267/94, ECLI:EU:T:1997:113, t. 20, Presuda od 9. rujna 2008, MyTravel/Komisija, T-212/03, ECLI:EU:T:2008:315, t. 35, Presuda od 19. travnja 2012, Artegodan/Komisija, C-221/10 P, ECLI:EU:C:2012:216, t. 80, Presuda od 16. svibnja 2013, Gap granen \& producten/Komisija, T-437/10, ECLI:EU:T:2013:248, t. 16, Presuda od 26. veljače 2016, Spojeni predmeti T-546/13, T-108/14 i T-109/14, Šumelj i drugi, ECLI:EU:T:2016:107, t. 39.

25 Vid. npr.: Presuda od 10. srpnja 2014, Nikolaou/Revizorski sud, C-220/13 P, ECLI:EU:C:2014:2057, t. 52, Presuda od 26. veljače 2016, Spojeni predmeti T-546/13, T-108/14 i T-109/14, Šumelj i drugi, ECLI:EU:T:2 16:107, t. 39.

26 Vid. npr.: Presuda od 5. ožujka 1996, Brasserie du Pêcheur i Factortame, C-46/93 i C-48/93, ECLI:EU:C:1996:79, t. 5, Presuda od 4. srpnja 2000, Bergaderm i Goupil/Komisija, C-352/98 P, ECLI:EU:C:2000:361, t. 42. i 43, Presuda od 2. ožujka 2010, Arcelor/Parlament i Vijeće, T-16/04, ECLI:EU:T:2010:54, t. 141.

27 Povredu pravnog pravila Unija može izvršiti i protupravnim propuštanjem, ali Unija može odgovarati za štetu samo ako su njene institucije povrijedile pravnu obvezu djelovanja koja proizlazi iz odredaba prava Unije. Presuda od 26. veljače 2016, Spojeni predmeti T-546/13, T-108/14 i T-109/14, Šumelj i drugi, ECLI:EU:T:2 16:107, t. 39, t. 42.

28 Principles of European Tort Law (PETL). 
referentnog okvira za europsko privatno pravo $^{29}$ (DCFR). To su skupovi pravnih pravila neobvezujuće snage, nastali kao rezultat dugogodišnjeg rada brojnih pripadnika akademske zajednice i praktičara, ${ }^{30}$ uvjerenih da unatoč velikim razlikama u pravilima država članica EU postoji njihov zajednički temelj i potencijal za usvajanje jedinstvenih pravila o odgovornosti za štetu. Bez obzira što je s ove vremenske distance moguće primijetiti da su, barem za sada, izostali značajniji rezultati u tom smjeru, ${ }^{31}$ njihova su pravila svakako zaslužila da ih se uzme u obzir pri analizi svakog pojedinog pitanja odgovornosti za štetu na europskom nivou.

\subsection{ODGOVORNOST NA TEMELJU KRIVNJE I OBJEKTIVNA ODGOVORNOST U PETL}

Odgovornost na temelju krivnje i objektivna odgovornost za štetu samo su dvije od više različitih osnova odgovornosti koje PETL predviđa za pripisivanje štete određenom štetniku, koje se komplementarno primjenjuju. ${ }^{32}$

Prema članku 4:101. PETL-a, osoba je odgovorna po osnovi krivnje za povredu potrebnog standarda ponašanja učinjenu s namjerom ili nepažnjom i u članku 4:102. stavak 1 . se određuje da taj standard ponašanja obuhvaća standard razumne osobe (reasonable person) u okolnostima pojedinog slučaja. Očekivani standard ponašanja je objektivan, neovisan o individualnim karakteristikama i sposobnostima pojedinog pravnog subjekta, što oslikava pristup većine europskih odštetnopravnih sustava koji (ne)krivnju procjenjuju prema apstraktnim standardima ponašanja, a ne s obzirom na odnos konkretnog štetnika prema

29 Draft Common Frame of Reference for a European private law (DCFR).

30 PETL su rezultat rada Europske grupe za odštetno pravo. Više o PETL vid. Petrić, S., 2012, Načela europskog odštetnog prava (PETL), Zbornik radova Aktualnosti građanskog i trgovačkog zakonodavstva i pravne prakse, 10, str. 63-77 i Martin-Casals, M., The Principles of European Tort Law (PETL) at the beginning of a second decade, u: Giliker, P. (ed.), 2017, Research handbook on EU tort law, Cheltenham, Northampton, Edward Elgar Publishing, pp. 361-391. Autori DCFR-a bili su okupljeni u dvije osnovne grupe: Study Group on a European Civil Code (SGECC) i Research Group on the Existing EC Private Law (tzv. Acquis-group), a u izradi teksta sudjelovala je tzv. CFR mreža koju je Komisija osnovala od predstavnika gospodarskih subjekata, potrošačkih udruga, profesionalnih udruga pravnika, eksperata, iz svih država članica. O pozadini i tijeku donošenja DCFR-a, brojnim sudionicima istog i odnosu europskih institucija prema tom radu vrlo detaljno vid. kod: Petrić, S., 2009, Nacrt Zajedničkog referentnog okvira za europsko privatno pravo, Zbornik Pravnog fakulteta u Rijeci, 30(1), str. 473-513.

31 Vrhovni sudovi nekih država u svojim su odlukama citirali PETL i na njih se pozivali, a navode se i kao jedan od izvora inspiracije kod promjena zakonodavstava pojedinih država. Martin-Casals, M., 2017, pp. 367-370. Bez obzira na to, teško je zaključiti da je to odjek i primjena u praksi u mjeri koju se očekivalo. Europska grupa se i dalje sastaje i radi, te planira i donošenje nove verzije PETL-a. Ibid., p. 391.

32 PETL u članku 1:101. razlikuje tri osnove odgovornosti: odgovornost na temelju krivnje, objektivnu odgovornost za iznimno opasne aktivnosti te odgovornost za radnje pomoćnika. U članku 1:101. stavak 2. kada kaže „posebno“, implicira da to nisu jedine tri osnove odgovornosti, što potvrđuju i kasnije odredbe o odgovornosti za tzv. poduzetničku aktivnost (članak 4:202), ostavljanje da države predvide i odgovornost za ne tako iznimno opasne aktivnosti (članak 5:102), odgovornost za druge osobe - maloljetnike, duševno bolesne (članak $6: 101)$. 
štetnoj radnji i šteti. ${ }^{33}$ Objektiviziranje standarda ponašanja za potrebe procjene krivnje štetnika, međutim, za sobom povlači problem razlikovanja krivnje i protupravnosti kao odvojenih pretpostavki odgovornosti za štetu. ${ }^{34}$ PETL, međutim, uopće ne predviđaju protupravnost štetne radnje kao samostalnu pretpostavku odgovornosti, što se objašnjava naglašavanjem pojma štete kao povrede pravom zaštićenog interesa kojim je protupravnost implicite obuhvaćena. ${ }^{35}$

Brojni su kriteriji procjene je li određeni štetnik štetu prouzročio s krivnjom: priroda i vrijednost zaštićenog interesa, opasnost djelatnosti, stručnost pojedinog štetnika, predvidivost štete, bliskost odnosa ili povjerenje osoba uključenih u odnos odgovornosti za štetu, dostupnost i trošak prevencije ili alternativnih aktivnosti, dob osobe, psihičke ili fizičke teškoće zbog kojih se ne može pridržavati standarda ponašanja, izvanredne okolnosti zbog kojih se od nje ne može očekivati da se pridržava određenog standarda ponašanja. ${ }^{36}$ Upravo se ovako široka lepeza kriterija za procjenu potrebnog standarda ponašanja, uz zadržavanje njihove apstraktne prirode, smatra jednim od najboljih rješenja PETL-a. ${ }^{37}$

Odredba članka 4:201. stavak 1. PETL-a, prema kojoj se teret dokazivanja može prebaciti u svjetlu ozbiljnosti opasnosti određene djelatnosti, izazvala je posebnu pozornost pravne znanosti. Prebacivanje tereta dokazivanja s oštećenika na štetnika ${ }^{38}$ predviđa se u slučajevima u kojima je rizik nastanka štete veći od normalnog rizika svojstvenog ljudskoj djelatnosti (koji dovodi do subjektivne odgovornosti), ali ipak manji od rizika povezanih s neuobičajeno opasnom djelatnošću, koji dovodi do objektivne odgovornosti prema članku 5:101. PETL-a. Ozbiljnost opasnosti procjenjuje se prema značaju potencijalne štete i vjerojatnosti njena nastanka (članak 4:201. stavak 2. PETL). Osim kod povećanih rizika, PETL prebacivanje tereta dokaza predviđaju i za poduzetničke aktivnosti (članak 4:202. stavak 1). ${ }^{39}$

Neki autori u navedenoj odredbi o prebacivanju tereta dokaza vide pokušaj povezivanja subjektivne i objektivne odgovornosti i naglašavanje da među njima postoji kontinuitet i da su one dva različita kraja istog lanca odgovornosti. ${ }^{40}$ Upućene su joj i određene kritike, posebno u pogledu činjenice da uopće ne određuje na kojoj strani se polazno nalazi teret dokazivanja, budući da o

33 Martín-Casals, M., 2017, p. 380.

34 O protupravnosti i krivnji, odnosno njihovu razlikovanju u poredbenopravnim sustavima, vid. Koziol, H. et al., (ed.), 1998, Unification of Tort Law: Wrongfulness, The Hague, London, Boston, Kluwer Law International.

35 Petrić, S., 2012, str. 73.

36 PETL, članak 4:102. st. 1. i 2.

37 Kadner Graziano, T., 2018, Comparative Tort Law: Cases, Materials and Exercises, New York, Routledge, p. 53.

38 Upravo je neodređenost polazišne točke u pogledu tereta dokazivanja bila jedna od većih kritika upućenih ovom dijelu PETL, vid. infra.

39 Osobe koje se dugotrajnije bave takvom aktivnošću i pritom koriste pomoćnike ili tehničku opremu odgovorne su za svaku štetu nastalu nedostatkom te aktivnosti ili njenih rezultata osim ako ne dokažu da su se pridržavale potrebnog standarda ponašanja.

40 Martín-Casals, M., 2017, p. 383. 
tome postoje različita rješenja u poredbenim sustavima. ${ }^{41}$ Nadalje, to što se teret dokazivanja može prebaciti, prema nekim autorima daje sudovima prevelike diskrecijske ovlasti, jer sud može, ali ne mora ustanoviti da je teret dokazivanja prebačen. ${ }^{42}$ Kritici je podvrgnuta i jasnoća kriterija ozbiljnosti opasnosti, jer se značajnost i vjerojatnost nastanka štete ne smatraju dovoljno preciznim kriterijima za procjenu kada je rizik ostvaren u mjeri potrebnoj za to prebacivanje. Ako konkretna djelatnost u većini slučajeva dovodi do značajne štete, štetnici bi trebali odgovarati temeljem objektivne odgovornosti (prema članku 5:101. stavak 1), a ukoliko to nije slučaj, nejasno je kada je određeni rizik ostvaren u mjeri dovoljnoj za prebacivanje tereta dokaza, ali ne i za primjenu pravila objektivne odgovornosti. ${ }^{43}$

Budući da većina europskih država posebnim zakonskim odredbama predviđa objektivnu odgovornost za štetu nastalu opasnim djelatnostima s uključenim ozbiljnim rizikom nastanka štete, u tom su smjeru bili krenuli i prvi prijedlozi odredaba PETL-a. Autori su namjeravali propisati konkretne slučajeve objektivne odgovornosti, dok bi se u ostalim slučajevima primjenjivala pravila o subjektivnoj odgovornosti za štetu, bez ili sa prebacivanjem tereta dokazivanja. ${ }^{44}$ Međutim, o tim slučajevima nisu uspjeli postići dogovor, te je zato u članku 5:101. stavak 1. PETL-a usvojeno opće pravilo prema kojem je osoba koja poduzima neuobičajeno opasnu djelatnost objektivno odgovorna za štetu karakterističnu za rizik koju ta djelatnost predstavlja i od koje nastaje. PETL nadalje generalno propisuje da je određena djelatnost neuobičajeno opasna kada stvori predvidiv i vrlo značajan rizik štete čak i kada se u njenom izvođenju primijeni potreban stupanj dužne pozornosti, kao i kada takva djelatnost ne spada u uobičajenu uporabu. ${ }^{45} \mathrm{U}$ članku 5:102. stavak 1. PETL-a ostavljena je mogućnost nacionalnim sustavima da propišu daljnje kategorije objektivne odgovornosti za opasne djelatnosti čak i kada djelatnost nije neuobičajeno opasna, ${ }^{46}$ te u stavku 2. da se, osim ako nacionalno pravo ne predviđa drugačije, dodatne kategorije objektivne odgovornosti mogu ustanoviti analogijom kod drugih izvora usporedivih rizika štete. ${ }^{47}$

Upravo je regulacija objektivne odgovornosti u PETL-u doživjela najveću kritiku. Nejasnim je ocijenjen razlog za svrstavanje pod objektivnu odgovornost samo slučajeva štete od opasnih djelatnosti predvidivih uzroka, a neshvatljivim se smatra zašto bi štetnici trebali objektivno odgovarati samo za opasne djelatnosti koje ne spadaju u uobičajenu uporabu, jer to ne odražava trenutno stanje

41 Giesen, I., 2010, The reversal of the burden of proof in the Principles of European Tort Law: A comparison with Dutch tort law and civil procedure rules, Utrecht Law Review, Vol. 6, No. 1, p. 24.

42 Ibid., p. 26.

43 Ibid., pp. 26-27.

44 Martín-Casals, M., 2017, p. 385.

45 PETL, članak 5:101. stavak 2.

46 PETL, članak 5:102. stavak 1.

47 PETL, članak 5:102. savak 2. 
odštetnih pravila u europskim državama. ${ }^{48}$ Odredba kojom PETL upućuju da se u nacionalnim pravima može propisati i šira primjena objektivne odgovornosti od njima obuhvaćene, smatra se suprotnom samoj unifikacijskoj svrsi PETL-a. ${ }^{49}$ Također, omogućavanje nacionalnim sudovima da samostalno, primjenom analogije ustanove postojanje objektivne odgovornosti u slučajevima izvan PETL-a, ocijenjeno je kontradiktornim. ${ }^{50}$

\subsection{ODGOVORNOST NA TEMELJU KRIVNJE I OBJEKTIVNA ODGOVORNOST U ODREDBAMA KNJIGE VI DCFR-A}

Za razliku od PETL-a, DCFR uopće ne koristi opći pojam krivnje, kao ni pojam objektivna odgovornost za štetu. Podjela na odgovornost na temelju krivnje i objektivnu odgovornost proizlazi iz načina na koji su slučajevi odgovornosti za štetu kvalificirani na one u kojima je šteta prouzročena namjerno ili iz nepažnje (dakle, s krivnjom) i one kod kojih namjera ili nepažnja ne postoji. ${ }^{51} \mathrm{Za} \mathrm{razliku} \mathrm{od}$ većine nacionalnih sustava u kojima je definiranje namjere i nepažnje prepušteno pravnoj znanosti i sudskoj praksi, tvorci DCFR-a su definirali oba oblika krivnje. Namjerno je štetu prouzročila osoba koja je htjela prouzročiti tu vrstu štete ili određeno ponašanje znajući da će takva vrsta štete biti ili gotovo sigurno biti prouzročena. ${ }^{52}$ Nepažnjom je štetu prouzročila osoba čije ponašanje ili ne udovoljava posebnim standardima pažnje koje propisuju odredbe propisa čiji je cilj zaštita oštećenih osoba od pretrpljene štete, ili na drugi način ne dostiže pažnju koja se može očekivati od razumno pažljive osobe u okolnostima slučaja. ${ }^{53}$

Za objektivnu odgovornost za štetu DCFR koristi pojam odgovornost bez namjere ili nepažnje. ${ }^{54}$ Prvo navodi slučajeve takve odgovornosti: odgovornost za štetu koju prouzroče zaposlenici i zastupnici, odgovornost za štetu prouzročenu neispravnim stanjem nekretnine, odgovornost za štetu koju prouzroče životinje, odgovornost za neispravan proizvod, odgovornost za štetu prouzročenu motornim vozilom te odgovornost za štetu prouzročenu opasnim supstancama ili imisijama. ${ }^{55}$ Međutim, također ostavlja mogućnost i za primjenu objektivne odgovornosti izvan navedenih slučajeva: ako su propisani nacionalnim pravom a

48 Takvom odredbom isključuje se postojanje objektivne odgovornosti u cestovnim i željezničkim nesrećama, neovisno o činjenici što je u europskim odštetnopravnim sustavima gotovo postignuta jednoglasnost da bi trebalo da navedeni slučajevi spadaju pod objektivnu odgovornost. Kadner Graziano, T., 2018, p. 61.

Ibid.

50 Martín-Casals, M., 2017, p. 387.

51 Članak 101. stavak 1. prvog poglavlja (1:101(1)) predviđa da osoba koja pretrpi pravno priznati gubitak (štetu) ima pravo na popravljanje te štete od osobe koja ju je prouzročila namjerno ili iz nepažnje, ili je na drugi način odgovorna za njezino prouzročenje. Ako šteta nije prouzročena namjerno ili iz nepažnje, za nju se odgovara samo u slučajevima propisanim u trećem poglavlju (1:101(2)).

52 Knjiga VI, 3:101.

53 Knjiga VI, 3:102.

54 Accountability without intention or negligence.

55 Knjiga VI, 3:201- 3:206. 
šteta je u vezi s izvorima opasnosti izvan onih iz čl. 3:104 - 3:205, supstancama ili imisijama ili se ne primjenjuje pravilo o razvojnom riziku kao egzoneracijskom razlogu iz članka 3:204. stavak (4)(e). ${ }^{56}$

DCFR je, u odnosu na PETL, objektivnoj odgovornosti za štetu posvetio puno više odredaba, izričito predvidjevši tu vrstu odgovornosti za slučajeve za koje je većina nacionalnih poredaka propisuje (a ne samo za neuobičajeno opasnu djelatnost). Ali, i DCFR je otvorenom ostavio mogućnost da nacionalni zakonodavci prošire područje njene primjene.

\section{ZAKLJUČNE NAPOMENE}

S obzirom na izrazito heterogena rješenja pitanja vrste odgovornosti u nacionalnim pravnim sustavima država članica, ne čudi da se na europskom, nadnacionalnom nivou ne pronalazi njegovo jedinstveno rješenje. Europski je zakonodavac već pri uređenju odgovornosti za štete od neispravnog proizvoda, iako ju je odredio kao objektivnu, morao pristati na kompromisno rješenje. U brojnim kasnije donesenim direktivama koje sadrže odredbe o odgovornosti za štetu, zbog problema različitog pristupa krivnji u nacionalnim pravnim sustavima, pojam krivnje kao pretpostavke odgovornosti jednostavno se izbjegava. Slučajevi odgovornosti koji su se razvili isključivo kroz praksu Suda EU krivnju ne ističu kao posebnu pretpostavku odgovornosti za štetu, već je razmatraju u okviru ozbiljnosti povrede prava EU. Ni soft law izvori europskog odštetnog prava, iako je njihovu donošenju prethodila dugogodišnja analiza i usporedba pravila o odgovornosti za štetu država članica, nisu u potpunosti uspjeli precizno odrediti razliku između odgovornosti na temelju krivnje i objektivne odgovornosti za štetu i granice njihove primjene. Čini se da to može voditi zaključku da pitanje jasnog određenja vrste odgovornosti za štetu na europskom nivou ostaje trajno otvoreno.

\section{LITERATURA}

1. Baretić, M., 2005, Odgovornost za neispravan proizvod, u: Baretić, M. et al., Novi Zakon o obveznim odnosima - najznačajnije izmjene - novi instituti, Zagreb, Inženjerski biro.

2. Bukovac Puvača, M., 2009, „Sive zone“ izvanugovorne odgovornosti - područja moguće primjene pravila o odgovornosti na temelju krivnje i objektivne odgovornosti za štetu, Zbornik Pravnog fakulteta Sveučilišta u Rijeci, 30(1).

3. Bukovac Puvača, M., Butorac, V., 2008, Izvanugovorna odgovornost za štetu prouzročenu povredom pravila tržišnog natjecanja, Zbornik radova Šestog međunarodnog savjetovanja Aktualnosti građanskog i trgovačkog zakonodavstva i pravne prakse.

4. Giesen, I., 2010, The reversal of the burden of proof in the Principles of European Tort Law: A comparison with Dutch tort law and civil procedure rules, Utrecht Law Review, Vol. 6, No. 1. 
5. Giliker, P., What do we mean by „EU tort law“?, u: Giliker, P. (ed.). 2017, Research handbook on EU tort law, Cheltenham, Northampton, Edward Elgar Publishing.

6. Granger, M. P. F., Francovich liability before national courts: 25 years on, has anything changed? u: Giliker, P. (ed.), 2017, Research handbook on EU tort law, Cheltenham, Northampton, Edward Elgar Publishing.

7. Howells, G., Is European Product Liability Harmonised?, u: Koziol, H., Schulze, R. (eds.), 2008, Tort Law of the European Community, Wien, Springer.

8. Kadner Graziano, T., 2018, Comparative Tort Law: Cases, Materials and Exercises, New York, Routledge.

9. Knetsch, J., European tort law in Western Europe, u: Giliker, P. (ed.), 2017, Research handbook on EU tort law, Cheltenham, Northampton, Edward Elgar Publishing.

10. Koziol, H. et al., (ed.), 1998, Unification of Tort Law: Wrongfulness, The Hague, London, Boston, Kluwer Law International.

11. Leczykiewicz, D., Compensatory remedies in EU law: the relationship between EU law and national law, u: Giliker, P. (ed.), 2017, Research handbook on EU tort law, Cheltenham, Northampton, Edward Elgar Publishing.

12. Lukas, M., Fault Liability, u: Koziol, H., Schulze, R. (eds.), 2008, Tort Law of the European Community, Wien, Springer.

13. Martin-Casals, M., The Principles of European Tort Law (PETL) at the beginning of a second decade, u: Giliker, P. (ed.), 2017, Research handbook on EU tort law, Cheltenham, Northampton, Edward Elgar Publishing.

14. Okeoghene, O., Sanchez-Graells, A., The interface of EU and national tort law: competition law, u: Giliker, P. (ed.), 2017, Research handbook on EU tort law, Cheltenham, Northampton, Edward Elgar Publishing.

15. Petrić, S., 2009, Nacrt Zajedničkog referentnog okvira za europsko privatno pravo, Zbornik Pravnog fakulteta u Rijeci, 30(1).

16. Petrić, S., 2009, Usklađivanje europskog odštetnog prava, Zbornik radova Aktualnosti građanskog i trgovačkog zakonodavstva i pravne prakse, 7.

17. Petrić, S., 2012, Načela europskog odštetnog prava (PETL), Zbornik radova Aktualnosti građanskog i trgovačkog zakonodavstva i pravne prakse, 10.

18. Petrić, S., Bukovac Puvača, M., 2008, Problem razvojnih rizika kod odgovornosti za neispravan proizvod, Zbornik radova Aktualnosti građanskog i trgovačkog zakonodavstva i pravne prakse, 6.

19. Van Dam, C., 2013, European Tort Law, New York, Oxford University Press.

20. White, F., Directive 85/374/EEC concerning liability for defective products: in the name of harmonisation, the internal market and consumer protection, u: Giliker, P. (ed.), 2017, Research handbook on EU tort law, Cheltenham, Northampton, Edward Elgar Publishing.

\section{PROPISI}

1. Direktiva Vijeća $85 / 374 /$ EEZ od 25. srpnja 1985. o približavanju zakona i drugih propisa država članica u vezi s odgovornošću za neispravne proizvode, Sl. list EU L 210, 7. 8. 1985, str. 29-33 (Sl. list, posebno izdanje na hrvatskom jeziku, poglavlje 15, svezak 22, str. 3-7), izmijenjena i dopunjena Direktivom 1999/34/EZ Europskog parlamenta i Vijeća od 10. svibnja 1999. o izmjeni Direktive Vijeća 85/374/EEZ od 25. srpnja 1985. o usklađivanju zakona i drugih propisa država članica u vezi s 
odgovornošću za neispravne proizvode (Sl. list EU L 141, 4. 6. 1999, str. 20-21) (Sl. list, posebno izdanje na hrvatskom jeziku, poglavlje 15, svezak 12, str. 43-44) (Direktiva $85 / 374 /$ EEZ).

2. Direktiva 2014/104/EU Europskog parlamenta i Vijeća od 26. studenoga 2014. o određenim pravilima kojima se uređuju postupci za naknadu štete prema nacionalnom pravu za kršenje odredaba prava tržišnog natjecanja država članica i Europske unije, Sl. list EU, L 349, 5. 12. 2014, str. 1-19. (Direktiva 2014/104/EU).

3. Direktiva 95/46/EZ Europskog parlamenta i Vijeća od 24. listopada 1995. o zaštiti pojedinaca u vezi s obradom osobnih podataka i o slobodnom protoku takvih podataka (SL L 281, 23. 11. 1995) (Direktiva 95/46/EZ).

4. Uredba (EU) 2016/679 Europskog parlamenta i Vijeća od 27. travnja 2016. o zaštiti pojedinaca u vezi s obradom osobnih podataka i o slobodnom kretanju takvih podataka te o stavljanju izvan snage Direktive 95/46/EZ (Opća uredba o zaštiti podataka), Sl. list EU, L 119, 4. 5. 2016, str. 1-88 (Uredba (EU) 2016/679).

5. Zakon o obveznim odnosima, Narodne novine, br. 35/05, 41/08, 125/11, 78/15 i 29/18.

\section{SUDSKA PRAKSA}

1. Presuda od 19. studenog 1991, Andrea Francovich i Danila Bonifaci i dr./Republika Italija, Spojeni predmeti C-6 i 9/90, ECR I-05357, ECLI:EU:C:1991:428.

2. Presuda od 5. ožujka 1996, Brasserie du Pêcheur SA/Bundesrepublik Deutschland i The Queen Secretary of State for Transport, ex parte: Factortame Ltd i dr., Spojeni predmeti C-46/93 i C-48/93, ECR I-1066., ECLI:EU:C:1996:79.

3. Presuda od 11. srpnja 1997, Oleifici Italiani/Komisija, T-267/94, ECLI:EU:T:1997:113.

4. Presuda od 9. rujna 2008, MyTravel/Komisija, T-212/03, ECLI:EU:T:2008:315.

5. Presuda od 19. travnja 2012, Artegodan/Komisija, C-221/10 P, ECLI:EU:C:2012:216.

6. Presuda od 16. svibnja 2013, Gap granen \& producten/Komisija, T-437/10, ECLI:EU:T:2013:248.

7. Presuda od 26. veljače 2016, Spojeni predmeti T-546/13, T-108/14 i T-109/14, Šumelj i drugi, ECLI:EU:T:2016:107.

8. Presuda od 10. srpnja 2014, Nikolaou/Revizorski sud, C-220/13 P, ECLI:EU:C:2014:2057.

9. Presuda od 4. srpnja 2000, Bergaderm i Goupil/Komisija, C-352/98 P, ECLI:EU:C:2000:361.

10. Presuda od 2. ožujka 2010, Arcelor/Parlament i Vijeće, T-16/04, ECLI:EU:T:2010:54. 


\title{
FAULT LIABILITY AND STRICT LIABILITY IN EUROPEAN TORT LAW
}

\author{
Maja Bukovac Puvača
}

\section{SUMMARY}

The aim of this paper is to examine whether at European level there is a basis for distinguishing between liability based on fault and strict liability and determining the limits of their application. Due to the indirect competences for interventions in the private law of the member states, the harmonization of the rules on liability for damage is approached selectively and partially by the European legislator. Therefore, in European legislation there is no clear determination of the type of liability. Soft law sources of European tort law, PETL and Book VI. DCFR, have tried to systematically regulate liability cases based on fault and strict liability, but neither have been completely successful, leaving national systems the option of prescribing additional categories of strict liability.

Key words: fault, strict liability, dangerous thing/activity, PETL, DCFR. 